\title{
Angiotensin l-converting enzyme-inhibitory activity of the Norwegian autochthonous cheeses Gamalost and Norvegia after in vitro human gastrointestinal digestion
}

\author{
T. M. Qureshi, G. E. Vegarud, R. K. Abrahamsen, and S. Skeie ${ }^{1}$ \\ Department of Chemistry, Biotechnology and Food Sciences, Norwegian University of Life Sciences, Chr. Magnus Falsens vei 1, \\ 1432 Ås, Norway
}

\begin{abstract}
The angiotensin I-converting enzyme (ACE) inhibitory activity of Gamalost cheese, its $\mathrm{pH}$ 4.6-soluble fraction, and Norvegia cheese was monitored before and after digestion with human gastric and duodenal juices. Both Gamalost and Norvegia cheeses showed an increased ACE-inhibitory activity during gastrointestinal digestion. However, only Norvegia showed pronounced increased activity after duodenal digestion. More peptides were detected in digested Gamalost compared with digested Norvegia. Most of the peptides in Gamalost were derived from $\beta$-casein $(\mathrm{CN})$, some originated from $\alpha_{\mathrm{s1}} \mathrm{CN}$, and only a very few originated from $\alpha_{\mathrm{s} 2}-\mathrm{CN}$ and $\kappa$-CN. In general, the number of peptides increased during gastrointestinal digestion, whereas some peptides were further degraded and disappeared; however, surprisingly, a few peptides remained stable. The aromatic amino acids, such as Tyr, Phe, and Trp; the positively charged amino acids (Arg and Lys); and Leu increased after simulated gastrointestinal digestion of Gamalost and Norvegia. After in vitro gastrointestinal digestion, both Gamalost and Norvegia showed high ACE-inhibitory activity, which may contribute in lowering of mild hypertension.
\end{abstract}

Key words: Gamalost, angiotensin I-converting enzyme inhibition, human gastrointestinal digestion, peptide composition

\section{INTRODUCTION}

Gamalost, an autochthonous mold (Mucor mucedo)ripened Norwegian cheese, is made by acid precipitation of fermented pasteurized skim milk and has been shown to have a high angiotensin I-converting enzyme (ACE)-inhibitory effect (Pripp et al., 2006; Qureshi et al., 2012). Gamalost differs from other mold cheeses by

Received July 29, 2012.

Accepted October 15, 2012.

${ }^{1}$ Corresponding author: siv.skeie@umb.no having a low fat content $(<0.05 \%$ fat $)$ and by the inactivation of the starter bacteria due to intensive cooking of the cheese curd in whey for 1 to $2 \mathrm{~h}$ at 90 to $95^{\circ} \mathrm{C}$ before the mold is added to the cheese. The development of ACE inhibitory peptides in Gamalost during ripening has previously been investigated (Qureshi et al., 2012), and it was found that the ACE inhibition of the $\mathrm{pH}$ 4.6-soluble fraction (SF) differed during ripening due to development of potential bioactive peptides.

A large number of bioactive peptides have been identified in milk, fermented dairy products, and cheeses (Meisel, 1998; Clare and Swaisgood, 2000; FitzGerald et al., 2004; Silva and Malcata, 2005; Sieber et al., 2010). These peptides have no bioactivity in the parent protein but are released during fermentation and hydrolysis by native enzymes, rennet enzymes, and bacterial enzymes in the cheese and further by digestive enzymes (FitzGerald et al., 2004; Korhonen and Pihlanto, 2006).

For a long time, commercial enzymes such as pepsin, trypsin, and chymotrypsin from nonhuman origin have been used in simulated human digestion, and many peptides have been identified as a result of such digestion experiments. Only a few studies have been carried out using human gastrointestinal (GI) enzymes under physiological conditions to identify the peptides formed (Mullally et al., 1997; Abubakar et al., 1998; Parrot et al., 2003; Gómez Ruiz et al., 2004; Hernández-Ledesma et al., 2004; Almaas et al., 2006b; Schmelzer et al., 2007). Different peptide patterns have been observed when using commercial enzymes compared with human enzymes. The in vitro human enzyme digestion results seem to be more consistent with the in vivo digestion studies reported (Chabance et al., 1998; Almaas et al., 2006a; Eriksen et al., 2010).

Human digestion depends on many factors such as composition of the food, gastric $\mathrm{pH}$, buffering capacity of the food, transit time, and concentrations and activities of the digestive enzymes and other digestive components (Dressman et al., 1990; Ekmekcioglu, 2002; Moreno, 2007). Gastric juice contains hydrochloric acid, pepsin, mucous, and gastric lipase (only in newborns), whereas pancreatic juice has high contents of bicarbon- 
ate, bile salts, and digestive enzymes such as trypsin, chymotrypsin, amino and carboxypeptidases, amylase, lipase, and enzymes that aid in digestion of nucleic acids and phospholipids (Ulleberg et al., 2011; Campbell, 2012). Generally, gastric $\mathrm{pH}$ ranges from 1 to 3.5 during the fasting period. However, the gastric $\mathrm{pH}$ range measured in healthy adults following a meal was 3.9 to 5.5 , depending on the buffering capacity of the food. The duodenal $\mathrm{pH}$ is normally around 6.0 to 7.8 (McCloy et al., 1984; Russell et al., 1993; Ekmekcioglu, 2002; Kalantzi et al., 2006; Campbell, 2012).

Studies on ACE inhibition after digestion with commercial enzymes have been performed on different milk proteins such as $\beta-\mathrm{LG}, \alpha-\mathrm{LA}$, whey protein concentrates, and cheese. In these studies, some antihypertensive peptides of $\beta-\mathrm{CN}$, including the potent Val-Pro-Pro and Ile-Pro-Pro peptides, have been identified (Mullally et al., 1997; Parrot et al., 2003; Vermeirssen et al., 2003; Gómez Ruiz et al., 2004; Ohsawa et al., 2008). To our knowledge, no in vitro digestion studies of cheese using human gastric juice (HGJ) and human duodenal juice (HDJ) evaluating the ACE-inhibitory potential of the cheese digests have been published. Therefore, it would be interesting to follow the ACE-inhibitory activity of Gamalost, which is known to have high ACE-inhibitory activity (Qureshi et al., 2012), and Norvegia, which is representative of cheese varieties used by many consumers in Norway, during digestion with human gastric and duodenal juices. The main objective of the present study was to evaluate the ACE-inhibitory activity of 2 Norwegian cheeses (Gamalost and Norvegia) during digestion with human gastric and duodenal juices and to characterize the peptides and amino acids in the digests.

\section{MATERIALS AND METHODS}

\section{Collection and Ripening of Cheese}

Gamalost cheese, produced as described by Qureshi et al. (2012), was kindly supplied by TINE Meieriet Vik (Oslo, Norway). Five cheeses from each of 3 separate productions were selected randomly at the dairy. One cheese was frozen $\left(-20^{\circ} \mathrm{C}\right.$ ) at age 0 (after cooking of the cheese in whey but before applying the mold at the surface of the cheese), the remaining 4 cheeses were frozen after $10 \mathrm{~d}$ of ripening. The frozen 10 -d-old cheeses were thawed and one from each batch was further ripened at the Norwegian University of Life Sciences, Department of Chemistry, Biotechnology and Food Science (Ås, Norway) at $4^{\circ} \mathrm{C}$.

The cheeses were sampled after 0,10 , and $30 \mathrm{~d}$ of ripening, ground, and frozen until digestion and further analysis. The sampling of the cheeses was done accord- ing to International Dairy Federation (IDF) standard 50C (IDF, 1995) and the cheese was grated with a manual grinder. From each sampling, a pH 4.6 SF was prepared according to the procedure described by Pripp et al. (2006). Three Norvegia cheeses (90 d old) were purchased from a local grocery shop, and used for comparison with Gamalost. The Gamalost cheese, its $\mathrm{pH} 4.6 \mathrm{SF}$, and Norvegia were further used in simulated digestion experiments.

\section{Aspiration of Human Gastric and Duodenal Juices and Their Activities}

Human gastric and duodenal juices were collected from healthy volunteers according to Ulleberg et al. (2011). The juices were collected from 20 fasting volunteers ( 7 men and 13 women; average age, $25 \pm 5$ yr). The collected juices were mixed together to make a batch as the juices vary in their activity from individual to individual. The main advantage of making a batch of juices was to reduce the variations in enzyme activity between the individual samples. The collected juices were centrifuged $(4,500 \times g$ for $10 \mathrm{~min})$ to remove mucous and cell debris before storing at -20 or $-80^{\circ} \mathrm{C}$. The pepsin activity of human gastric juices was measured as described by Sánchez-Chiang et al. (1987), whereas the total proteolytic activity of the human duodenal juices was measured as described by Krogdahl and Holm (1979).

\section{In Vitro Enzymatic Digestion}

An in vitro digestion model was performed to simulate human digestion in the stomach (step 1) and the duodenum (step 2) according to Almaas et al. (2006a), with some modifications. The Gamalost (2 g; containing $\sim 50 \%$ protein), Norvegia (4 g; containing $\sim 26 \%$ protein), and the $\mathrm{pH} 4.6 \mathrm{SF}(150 \mathrm{mg})$ of Gamalost were dissolved in $10 \mathrm{~mL}$ of physiological solution $(0.9 \%$ $\mathrm{NaCl}$ ). To mimic chewing in the mouth, the sample was incubated $\left(37^{\circ} \mathrm{C}\right)$ for 5 to $7 \mathrm{~min}$ in a Stomacher (Seward stomacher 400; Seward Ltd., West Sussex, UK) with constant shaking. To simulate the gastric phase (step 1 ), the $\mathrm{pH}$ was slowly decreased to 2.5 by dropwise addition of $2 \mathrm{M} \mathrm{HCl}$ after adding HGJ (15 U/g of protein) and the samples were incubated $(0.5 \mathrm{~h}$ for the $\mathrm{pH} 4.6$ $\mathrm{SF}$ and $1 \mathrm{~h}$ for the cheeses) at $37^{\circ} \mathrm{C}$ in a stomacher. The following duodenal digestion (step 2) was performed by $\mathrm{pH}$ adjustment to 7 by $4 \mathrm{M} \mathrm{NaOH}$ and then incubated with HDJ (31.2 U/g of protein; $1 \mathrm{~h}$ for the $\mathrm{pH} 4.6 \mathrm{SF}$ and $3 \mathrm{~h}$ for cheeses) at $37^{\circ} \mathrm{C}$. Samples $(0.3-0.5 \mathrm{~mL})$ were collected before digestion, after gastric digestion (step 1) and after the subsequent duodenal digestion (step 2). To stop the enzymatic reaction, the samples 
were immediately transferred to an ice bath and frozen $\left(-20^{\circ} \mathrm{C}\right)$. The digestion of each sample was performed in duplicate.

Before further analysis, the samples were thawed and the digestive enzymes were separated from the sample by ultrafiltration through hydrophilic membranes (Amicon Ultra, cut-off molecular weight $=10 \mathrm{kDa}$; Millipore BV, Carrigtwohill, Cork, Ireland) by centrifugation $\left(11,148 \times g\right.$ for $40 \mathrm{~min}$ at $\left.4^{\circ} \mathrm{C}\right)$. The peptides having molecular weight lower than $10 \mathrm{kDa}$ were collected in the permeate for all the samples.

\section{Chemical Analysis of Cheese}

The DM content of Gamalost was determined according to IDF standard 4/ISO 5534 (IDF, 2004). The soluble nitrogen (SN) content of the $10-\mathrm{kDa}$ permeate of Gamalost cheese and of Norvegia cheese, and the $\mathrm{pH}$ 4.6 SF of Gamalost cheese as well as the total nitrogen $(\mathbf{T N})$ content of Norvegia cheese were determined by the Kjeldahl method (IDF, 1993). A homogeneous sample for TN of Gamalost was difficult to obtain due to formation of precipitates during sample preparation. In addition, due to the presence of denatured whey proteins, foaming occurred during the digestion step in the preparation of the Gamalost sample for TN. Therefore, $\mathrm{SN} / \mathrm{DM}$ of the Gamalost was used instead of SN/TN.

\section{Identification of Peptide Sequences}

Nano-liquid chromatography-mass spectrometry of desalted and concentrated samples was performed according to Qureshi et al. (2012) following the method described by Eriksen et al. (2010), with some modifications. Only peptides with mass above 800 and below 4,500 Da were subjected to collision-induced fragmentation and further processing.

\section{Free Amino Acid Composition}

For the analysis of amino acid composition, the samples were prepared as described by Qureshi et al. (2012), with reversed-phase HPLC using o-phthalaldehyde and fluorenylmethyloxycarbonyl chloride derivatization, following the procedure of Bütikofer and Ardö (1999), with some modifications. One hundred microliters of the $10-\mathrm{kDa}$ permeate of all the samples was mixed with $100 \mu \mathrm{L}$ of $0.1 M \mathrm{HCl}$ containing $0.4 \mu \mathrm{mol} / \mathrm{mL}$ of $\mathrm{L}^{-}$ norvaline (Sigma, St. Louis, MO) and $0.4 \mu \mathrm{mol} / \mathrm{mL}$ of piperidine-4-carboxylic acid (Fluka, St. Louis, MO), and used as internal standards.

\section{Preparation of Samples for ACE-Inhibition Assay}

The ACE-inhibition assays were performed using the reaction of substrate (hippuryl-histidyl-leucine; Sigma) and enzyme (extract from rabbit lung acetone powder; Sigma), with measurement of the liberated hippuric acid (HA) by reversed-phase HPLC according to Qureshi et al. (2012), following the method described by Hyun and Shin (2000), with some modifications. Forty microliters of the $10-\mathrm{kDa}$ permeate of all samples was used in the assay. Captopril $\left(\mathrm{C}_{9} \mathrm{H}_{15} \mathrm{NO}_{3} \mathrm{~S}\right.$; Sigma), a blood pressure-lowering pharmaceutical, was used as an inhibitory reference. The ACE inhibition (\%) was calculated by using Equation 1 given below:

$$
\operatorname{ACE} \text { inhibition }(\%)=\frac{\mathrm{HA} \text { control }-\mathrm{HA}(\text { sample })}{\mathrm{HA}(\text { control })} \times 100
$$

where HA (control) denotes the concentration of hippuric acid liberated after reaction of enzyme and substrate (without sample), whereas HA (sample) represents the hippuric acid released after the reaction of enzyme and substrate in the presence of the sample. The estimated volume of $10-\mathrm{kDa}$ permeates extracted from $1 \mathrm{~g}$ of Gamalost was $5 \mathrm{~mL}$, whereas the estimated volume of $10-\mathrm{kDa}$ permeates extracted from $1 \mathrm{~g}$ of Norvegia was $2.5 \mathrm{~mL}$ (as described in the in vitro enzymatic digestion section). The results of the $10-\mathrm{kDa}$ permeates were calculated as the amount of cheese. Hence, the half maximal inhibitory concentration $\left(\mathbf{I C}_{50}\right)$, which is the inhibitory concentration of the sample of the freezedried $\mathrm{pH}$ 4.6 SF (in $\mathrm{mg} / \mathrm{mL}$ or in milligram equivalent cheese per milliliter) required to inhibit $50 \%$ of the ACE activity was determined from the linear regression equation by plotting ACE inhibition (\%) versus the inhibitory concentration of each dilution of the sample. The $\mathrm{IC}_{\mathrm{s}}$ was calculated using the following Equation 2:

$$
\mathrm{IC}_{\mathrm{s}}=\left(\mathrm{C}_{0} \times \mathrm{V}_{\mathrm{s}} \times \mathrm{L}\right) / \mathrm{V},
$$

where $\mathrm{C}_{0}$ is the initial sample concentration $(\mathrm{mg} / \mathrm{mL})$, $\mathrm{V}_{\mathrm{s}}$ is the sample volume $(40 \mu \mathrm{L}), \mathrm{L}$ denotes the dilutions used $(0.5,0.25$, and 0.125$)$, and $\mathrm{V}$ is the total reaction volume $(340 \mu \mathrm{L})$. From the $\mathrm{IC}_{50}$ values of the freeze-dried $\mathrm{pH} 4.6 \mathrm{SF}$, the $\mathrm{IC}_{50}$ values of the $\mathrm{pH} 4.6 \mathrm{SF}$ were also calculated as amount of Gamalost by using the weight $(\mathrm{g})$ of freeze-dried $\mathrm{pH} 4.6 \mathrm{SF}$ extracted from $1 \mathrm{~g}$ of cheese. The ACE-inhibitory potential (IP) per unit cheese weight ( $\mathrm{mg}$ of captopril Eq/kg of cheese) was calculated by Equation 3 given below:

$\mathrm{ACE}(\mathrm{IP})=\frac{\mathrm{IC}_{50}(\text { captopril }) \times \mathrm{pH} 4.6 \mathrm{SF} \text { or cheese amount }}{\mathrm{IC}_{50}(\mathrm{pH} 4.6 \mathrm{SF})}$,

where $\mathrm{IC}_{50}$ (captopril) and $\mathrm{IC}_{50}(\mathrm{pH} 4.6 \mathrm{SF})$ are the concentrations $(\mathrm{mg} / \mathrm{mL})$ of captopril and the freeze- 
dried $\mathrm{pH} 4.6 \mathrm{SF}(\mathrm{mg} / \mathrm{mL})$, respectively, whereas $\mathrm{pH}$ 4.6 SF and cheese amount represent the amount $(\mathrm{mg})$ of freeze-dried powder from $1 \mathrm{~g}$ of cheese and amount of cheese $(\mathrm{mg})$ present in $1 \mathrm{~mL}$ of the physiological solution $(0.9 \% \mathrm{NaCl})$, respectively.

\section{Statistical Analysis}

Statistical analysis was performed by Minitab statistical software version 15 (Minitab Inc., State College, PA). The Shapiro-Wilk test was used for testing the assumption of normal distribution of the data, which were satisfied for all variables. Individual cheeses from the same batch were assumed to be independent. Two-way ANOVA was performed with replicate block (random variable) and age (fixed variable) of Gamalost cheese to test the null hypothesis $\mathrm{H}_{0}$ : that the ACEinhibitory activity in the Gamalost and its $\mathrm{pH} 4.6$ SF did not change during ripening. Similarly, 2-way ANOVA was carried out with replicate block (random variable) and digestion steps (fixed variable; including undigested samples) and Norvegia to test $\mathrm{H}_{0}$ : that the ACE-inhibitory activity did not change during digestion of Gamalost and its $\mathrm{pH} 4.6 \mathrm{SF}$ at each ripening stage and Norvegia at $90 \mathrm{~d}$. The Tukey test for pairwise comparison was used to test the differences between means. For all comparisons, the level of significance was set to $P<0.05$.

\section{RESULTS}

\section{SN of Gamalost, Its pH 4.6 SF, and Norvegia Cheese}

The SN/DM (\%) of the $10 \mathrm{kDa}$ permeates of Gamalost and its $\mathrm{pH}$ 4.6 SF and SN/TN (\%) of the 10 $\mathrm{kDa}$ permeates of Norvegia is presented in Table 1 . The SN/DM (\%) of Gamalost and its pH 4.6 SF increased during ripening as well as during subsequent digestion. A difference between the different batches of Gamalost was found during ripening on the content of SN/DM $(\%)$, whereas in the digested Gamalost, an effect of productions was found on the SN/DM (\%) after $30 \mathrm{~d}$ of ripening (results not shown). The SN/TN (\%) content of Norvegia cheese $(90 \mathrm{~d})$ also increased significantly during both the gastric and duodenal digestion, and the SN/TN (\%) of Norvegia reached its peak after duodenal digestion.

\section{ACE Inhibition During Ripening and After GI Digestion}

The results of the ACE-inhibition (\%) measurements and the $\mathrm{IC}_{50}$ values of Gamalost (10-30 d) and its $\mathrm{pH}$ 4.6 SF, and of Norvegia (90 d) are presented in Figures 1 and 2, respectively. Optimum ACE-inhibitory activity
(\%) and the lowest $\mathrm{IC}_{50}$ values of the Gamalost and its $\mathrm{pH}$ 4.6 SF were observed after $10 \mathrm{~d}$ of ripening. Digestion affected the ACE-inhibitory activity of Gamalost and its $\mathrm{pH}$ 4.6 SF, as well as Norvegia. The highest ACE-inhibitory activity of Gamalost was observed after gastric digestion, and further duodenal digestion did not seem to affect the ACE-inhibitory activity further. The $\mathrm{IC}_{50}$ values showed similar results after gastric and duodenal digestion of Gamalost (Figure 2). By recalculation of the $\mathrm{IC}_{50}$ of the $\mathrm{pH} 4.6 \mathrm{SF}$ to the corresponding amount of the original Gamalost (10 and $30 \mathrm{~d})$, the trend was similar to what was found for the $\mathrm{pH} 4.6 \mathrm{SF}$. The $\mathrm{IC}_{50}$ values were higher in the Gamalost cheese before digestion (2.36 and 1.85 in Gamalost and the recalculated $\mathrm{pH} 4.6 \mathrm{SF}$, respectively, at $10 \mathrm{~d}$ ) and lower in Gamalost after gastric digestion (0.82 and 1.65 in Gamalost and the recalculated pH 4.6 SF, respectively, at $10 \mathrm{~d}$ ) as well as duodenal digestion (0.99 and 2.22 in Gamalost and the recalculated $\mathrm{pH} 4.6 \mathrm{SF}$, respectively, at $10 \mathrm{~d}$ ). Unlike Gamalost, Norvegia showed a gradual increase in the ACE-inhibitory activity, with a drastic decrease in $\mathrm{IC}_{50}$ values after the successive gastric and duodenal digestion. However, Gamalost differed from Norvegia by showing much lower $\mathrm{IC}_{50}$ values at all digestion steps. The $\mathrm{IC}_{50}$ value of captopril measured in the assay was $4.1 \times 10^{-6} \pm 1.3 \times 10^{-7} \mathrm{mg} / \mathrm{mL}$. An influence of different productions was observed on the $\mathrm{IC}_{50}$ values of Gamalost during ripening, whereas no influence of production was found on the ACE inhibition (\%) of Gamalost cheese during ripening. An effect of different productions was observed on the ACE inhibition (\%) of $\mathrm{pH} 4.6 \mathrm{SF}$ at 30-d Gamalost during GI digestion. An effect of different productions was also found on the $\mathrm{IC}_{50}$ values in 30-d Gamalost during GI digestion (results not shown).

On the basis of the results of the $\mathrm{IC}_{50}$ values of Gamalost, its $\mathrm{pH}$ 4.6 SF, and Norvegia, the ACE IP per unit of cheese weight was calculated (Figure 3). Gamalost cheese as well as its respective $\mathrm{pH}$ 4.6 SF showed high ACE IP after gastric digestion, but after duodenal digestion the IP values were somewhat reduced. Norvegia, however, showed an increasing trend after subsequent digestion, but its ACE IP remained at lower levels compared with Gamalost.

\section{Peptides Generated During Ripening and After GI Digestion}

Many peptides were identified during ripening and GI digestion. A summary table (Table 2) shows the number of peptides present before and after digestion of Gamalost, its pH 4.6 SF, and Norvegia. Most peptides derived from $\beta-\mathrm{CN}$, whereas some were released from $\alpha_{\mathrm{s} 1}-\mathrm{CN}$ and only a few derived from $\alpha_{\mathrm{s} 2}-\mathrm{CN}$ and $\kappa-\mathrm{CN}$. 


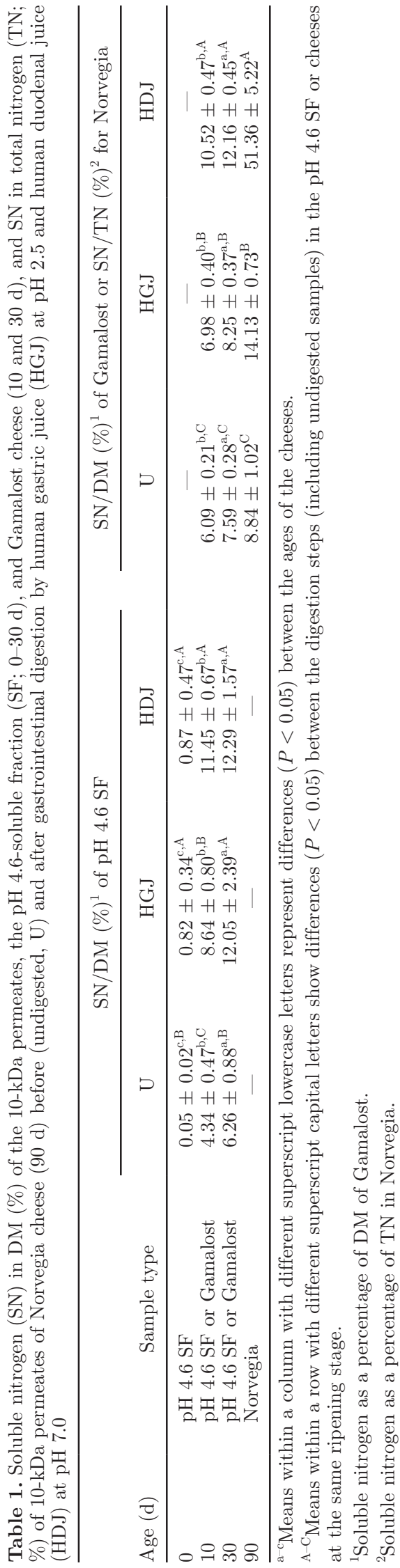

In short, Gamalost cheese contained almost twice as many peptides as detected in its $\mathrm{pH} 4.6 \mathrm{SF}$ and Norvegia.

In general, most of the peptides that were present in Gamalost matched the peptides present in the $\mathrm{pH}$ 4.6 SF; however, only a few peptides were common between Norvegia and Gamalost cheese or its $\mathrm{pH} 4.6$ SF (Figures 4-8). The peptide pattern of Norvegia differed from that of Gamalost by a much lower content of peptides. The peptide pattern of Gamalost (10 and 30 d) differed between undigested, gastric, and duodenal digested samples, and digestion affected the peptide profile in different ways. Figures 4 and 5 show in more detail the peptide pattern derived from $\beta-\mathrm{CN}$ during gastric and duodenal digestion of Gamalost (10 and 30 d). Many new peptides were released after gastric and further duodenal digestion. The peptides that were stable during GI digestion of the 10-d-ripened Gamalost were $\beta$-CN (126-139), $\beta$-CN (129-139), $\beta$-CN (144-160), $\beta-\mathrm{CN}(192-207)$, and $\beta-\mathrm{CN}$ (193-207), and a few peptides in the 30 -d-ripened Gamalost $[\beta-\mathrm{CN}$ (78-91), $\beta$-CN (129-139), $\beta$-CN (144-160), and $\beta$-CN (193-207)] were also stable through GI digestion. In the $\mathrm{pH}$ 4.6 SF (10-30 d) of Gamalost, many peptides derived from $\beta$-CN were detected in the extract before digestion. Almost all of the peptides present in the undigested $\mathrm{pH} 4.6 \mathrm{SF}$ of Gamalost were also detected in the undigested Gamalost cheese. Some peptides derived from $\beta$-CN were common between the gastric digested and duodenal digested $\mathrm{pH}$ 4.6 SF (results not shown) and Gamalost. In Norvegia cheese, some peptides $[\beta-$ CN (193-206), $\beta-C N ~(194-209)$, and $\beta-C N ~(195-206)]$ remained stable during GI digestion; however, some new peptides were observed during digestion (Figure 6).

A lower number of peptides were derived from $\alpha_{\mathrm{s}^{-}}$ $\mathrm{CN}$ than from $\beta$-CN during GI digestion of Gamalost cheese (Figure 7). In Gamalost cheeses (10 and $30 \mathrm{~d}$ ), some new peptides derived from $\alpha_{\mathrm{s} 1}$-CN were generated during GI digestion, and only 1 peptide $\left[\alpha_{\mathrm{s} 1}-\mathrm{CN}\right.$ (180-194)] in 30-d Gamalost remained stable during GI digestion (Figure 7a and b). The $\mathrm{pH} 4.6 \mathrm{SF}$ from fresh cheese $(0 \mathrm{~d})$ contained a higher number of peptides derived from $\alpha_{\mathrm{s} 1}$-CN compared with the $\mathrm{pH} 4.6$ SF of 10- and 30-d-ripened cheese (results not shown). Figure $8 \mathrm{a}$ and $\mathrm{b}$ shows the peptides derived from $\alpha_{\mathrm{s} 2}{ }^{-}$ $\mathrm{CN}$ in Gamalost. Only 1 peptide $\left[\alpha_{\mathrm{s} 2}-\mathrm{CN}(99-115)\right]$ remained stable in the 10-d-old Gamalost cheese during GI digestion. In addition, Gamalost contained 2 peptides [ $\beta$-LG (124-136) and $\beta-\mathrm{LG}(124-139)]$ derived from $\beta$-LG (Table 2). In undigested Norvegia cheese, a few peptides such as $\alpha_{\mathrm{s} 1} \mathrm{CN}(1-13), \alpha_{\mathrm{s} 1} \mathrm{CN}(1-14)$, $\alpha_{\mathrm{s} 1} \mathrm{CN}(1-16), \alpha_{\mathrm{s} 1}-\mathrm{CN}(10-23), \alpha_{\mathrm{s} 1}-\mathrm{CN}(15-23)$, and $\alpha_{\mathrm{s} 1}-\mathrm{CN}(26-34)$ were derived from $\alpha_{\mathrm{s} 1}-\mathrm{CN}$. Only 1 peptide $\left[\alpha_{\mathrm{s} 2}-\mathrm{CN}(151-162)\right]$ from undigested samples and 1 


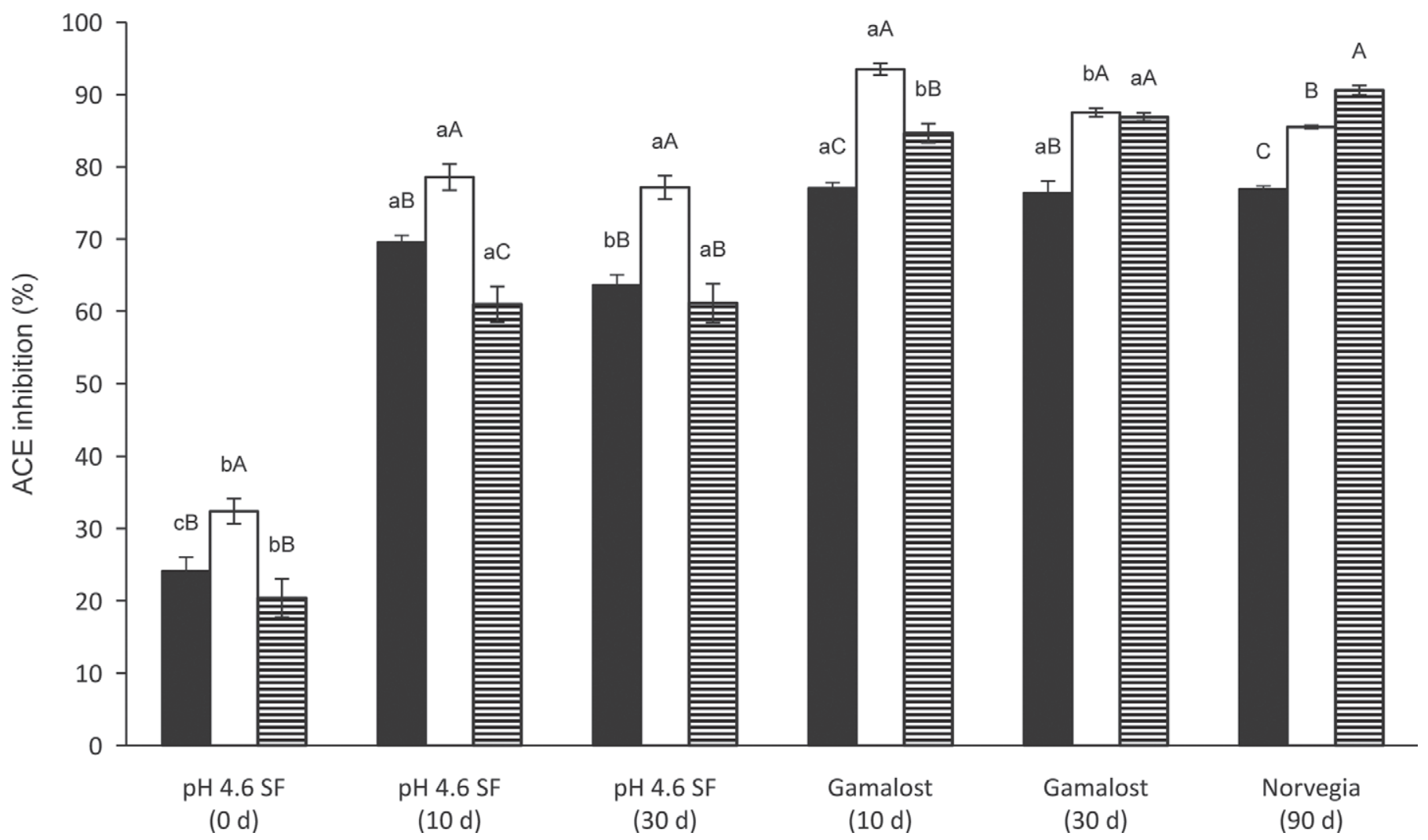

Figure 1. Angiotensin I-converting enzyme (ACE) inhibition (\%; mean $\pm \mathrm{SD}$ ) of the $<10$-kDa permeates of Gamalost cheese (10 and 30 d), its $\mathrm{pH}$ 4.6-soluble fraction (SF; 0-30 d), and Norvegia cheese before (undigested; black bars) and after gastrointestinal digestion by human gastric juice (HGJ; white bars) and human duodenal juice (HDJ; line pattern bars). Different lowercase letters (a-c) over the bars (except for Norvegia) represent significant differences $(P<0.05)$ between the ages of cheeses at the same digestion step, whereas different uppercase letters $(\mathrm{A}-\mathrm{C})$ show significant differences $(P<0.05)$ during digestion of the same sample at the same ripening stage.

$\left[\alpha_{\mathrm{s} 2}-\mathrm{CN}(100-114)\right]$ from HDJ digestion, derived from $\alpha_{\mathrm{s}^{2}}-\mathrm{CN}$, were present in Norvegia cheese (results not shown). From $\mathrm{k}-\mathrm{CN}$, only a few peptides were observed in Gamalost (30 d), pH 4.6 SF (0 d), and Norvegia (Table 3). During GI digestion, only 1 peptide $[\kappa-\mathrm{CN}$ (155-169)] derived from $\kappa-\mathrm{CN}$ in the $\mathrm{pH} 4.6 \mathrm{SF}$ from 0-d Gamalost, remained stable.

Most of the peptides identified in Gamalost, its $\mathrm{pH}$ 4.6 SF, and Norvegia had hydrophobic amino acids, such as Ala, Ile, Leu, Met, Phe, Trp, and Val, as well as Pro at any of the $3 \mathrm{C}$-terminal positions of peptides. In addition, positively charged amino acids such as Arg and Lys were detected at any of the $3 \mathrm{C}$-terminal positions of a few peptides. Moreover, most peptides in Gamalost, its respective $\mathrm{pH} 4.6 \mathrm{SF}$ and in Norvegia were generated from internal as well as from the $\mathrm{C}$-terminal sequences of $\beta-, \alpha_{\mathrm{s} 1^{-}}, \alpha_{\mathrm{s} 2^{-}}$, and $\kappa-\mathrm{CN}$.

\section{Free Amino Acid Contents Before and After GI Digestion}

The free amino acid contents $(\mathrm{mmol} / \mathrm{kg}$ ) of Gamalost $(10$ and $30 \mathrm{~d})$ and of Norvegia before and during diges- tion are presented in Figure 9a, b, and c. The amino acids Cit and $\gamma$-aminobutyric acid (GABA) were detected in negligible concentrations in Gamalost and Norvegia and were, therefore, omitted from Figure 9. Digestion affected the generation of free amino acids; the content of Pro decreased significantly during gastric digestion of Gamalost whereas the content of Arg, Tyr, Phe, Leu, and Lys were not influenced considerably by gastric digestion. However, after duodenal digestion, the content of these amino acids increased significantly. Norvegia (Figure $9 \mathrm{c}$ ) had very low concentrations of all amino acids compared with Gamalost; however, the amino acids Arg, Tyr, Phe, Trp, and Lys increased significantly after duodenal digestion of Norvegia.

\section{DISCUSSION}

In Gamalost, the increased ACE inhibition after gastric digestion indicates a possible further release of potent peptides during digestion. After digestion of Gamalost with HGJ and HDJ, the decreased $\mathrm{IC}_{50}$ values might be due to the generation of new peptides that may be more active as compared with the peptides present 


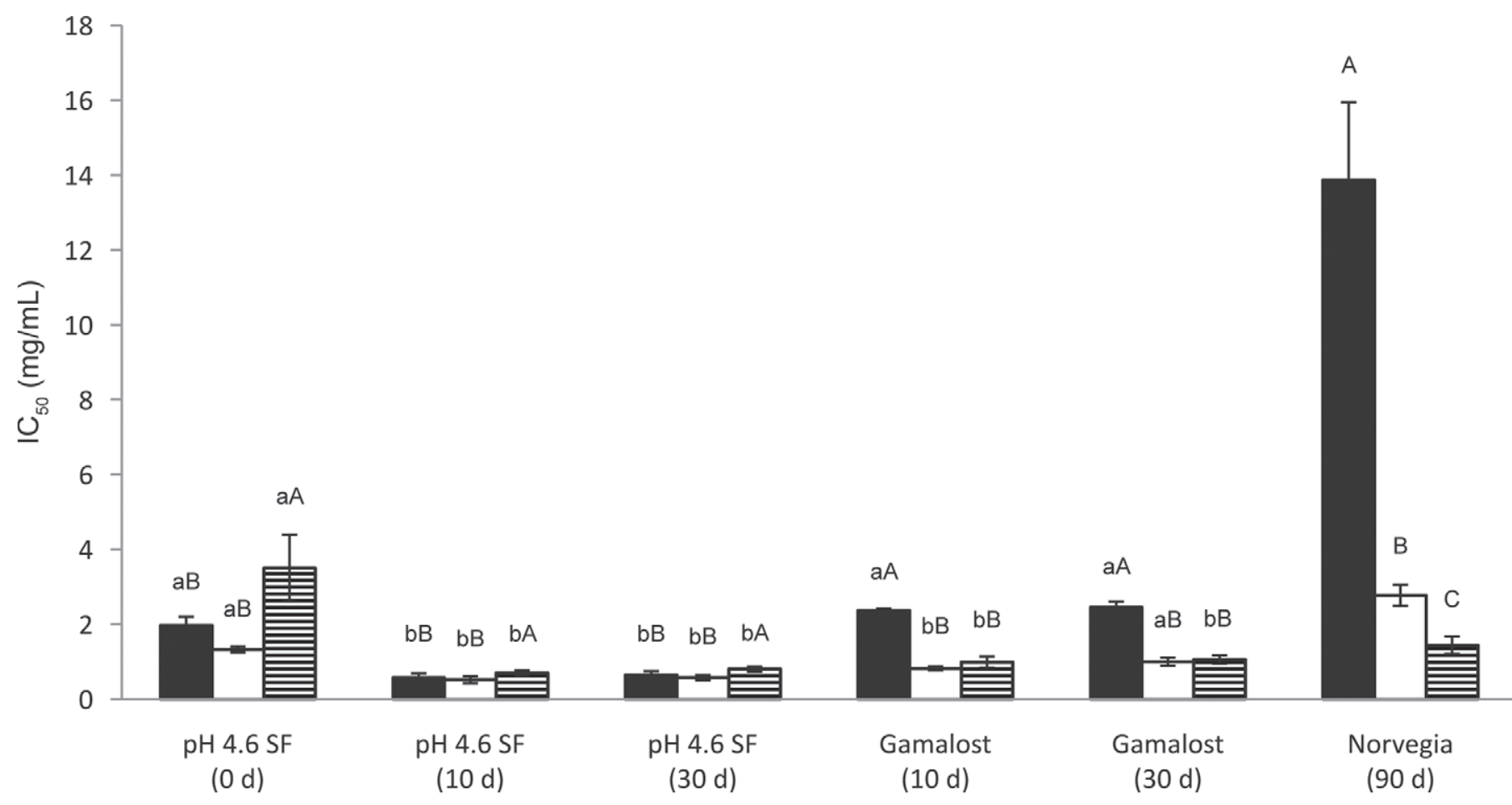

Figure 2. Inhibitory concentration required to inhibit $50 \%$ of the angiotensin I-converting enzyme (ACE) activity (IC $\left.{ }_{50}\right)$ values $($ mean \pm $\mathrm{SD})$ expressed as milligram equivalent per milliliter of Gamalost (10 and $30 \mathrm{~d}$ ) and Norvegia cheeses and pH 4.6-soluble fraction (SF; 0-30 d; $\mathrm{mg} / \mathrm{mL}$ ) of Gamalost before (undigested; black bars) and after gastrointestinal digestion by human gastric juice (HGJ; white bars) and human duodenal juice (HDJ; line pattern bars). Different lowercase letters (a and b) over the bars (except for Norvegia) represent significant differences $(P<0.05)$ between the ages of cheeses at the same digestion step, whereas different uppercase letters $(\mathrm{A}-\mathrm{C})$ show significant differences $(P<$ $0.05)$ during digestion of the same sample at the same ripening stage.

in the undigested cheese. The considerable decreasing trend of $\mathrm{IC}_{50}$ of Norvegia after GI digestion revealed that the released peptides might have a very high ACEinhibitory effect. The increased content of SN/TN (\%) of Norvegia after duodenal digestion is consistent with the results of Parrot et al. (2003), who found that the $\mathrm{SN} / \mathrm{TN}$ content increased drastically to almost $50 \%$ in Emmental cheese water-soluble extract (WSE) by the action of pepsin and trypsin. A considerable increase in Trp, Phe, and Tyr in the digests of Gamalost and Norvegia by human GI digestion is concurrent with the findings of Parrot et al. (2003) and Adt et al. (2011).

The WSE of Asiago d'allevo cheese with peptides having molecular mass less than $3 \mathrm{kDa}$ were reported to have a higher ACE-inhibitory activity than the WSE containing peptides larger than $3 \mathrm{kDa}$ (Lignitto et al., 2010). Most of the peptides observed in Gamalost, its $\mathrm{pH}$ 4.6 SF, and Norvegia had molecular masses lower than $3 \mathrm{kDa}$. López-Fandiño et al. (2006) reported that peptides with less than 27 amino acids had appreciable ACE-inhibitory activity. A slight difference existed in the $\mathrm{IC}_{50}$ values of the non-UF pH $4.6 \mathrm{SF}(0$ and $10 \mathrm{~d}$ ) in our previous study (Qureshi et al., 2012) and the UF $\mathrm{pH}$ 4.6 SF of the present study, as some of the peptides most probably were lost during UF of the samples in the present study. The difference in the $\mathrm{IC}_{50}$ values between the $\mathrm{pH} 4.6 \mathrm{SF}$ of Gamalost (10 and $30 \mathrm{~d}$ ) and Norvegia observed in the current study compared with the previously mentioned study (Qureshi et al., 2012), might be due to differences in the number of active peptides between different batches of cheese.

The presented results are consistent with previous reports regarding the structure-activity relationship between ACE inhibition and the available peptides (López-Fandiño et al., 2006; Haque and Chand, 2008). The presence of hydrophobic (Tyr, Phe, Trp, Ala, Ile, Leu, Val, and Met) or positively charged amino acids such as Arg and Lys as well as Pro at any of the 3 Cterminal positions of the peptides shows good binding of ACE (López-Fandiño et al., 2006; Haque and Chand, 2008; He et al., 2012). We observed that Gamalost also contained some of the peptides in which the 2 potent tripeptides Ile-Pro-Pro and Val-Pro-Pro were present in an encrypted form within their sequences. However, the $\mathrm{pH} 4.6 \mathrm{SF}$ of Gamalost and Norvegia contained very few of those peptides. The generation of a few peptides from the hydrophobic para- $\kappa-\mathrm{CN}$ in 30-d-old Gamalost and in Norvegia might explain the suscepti- 


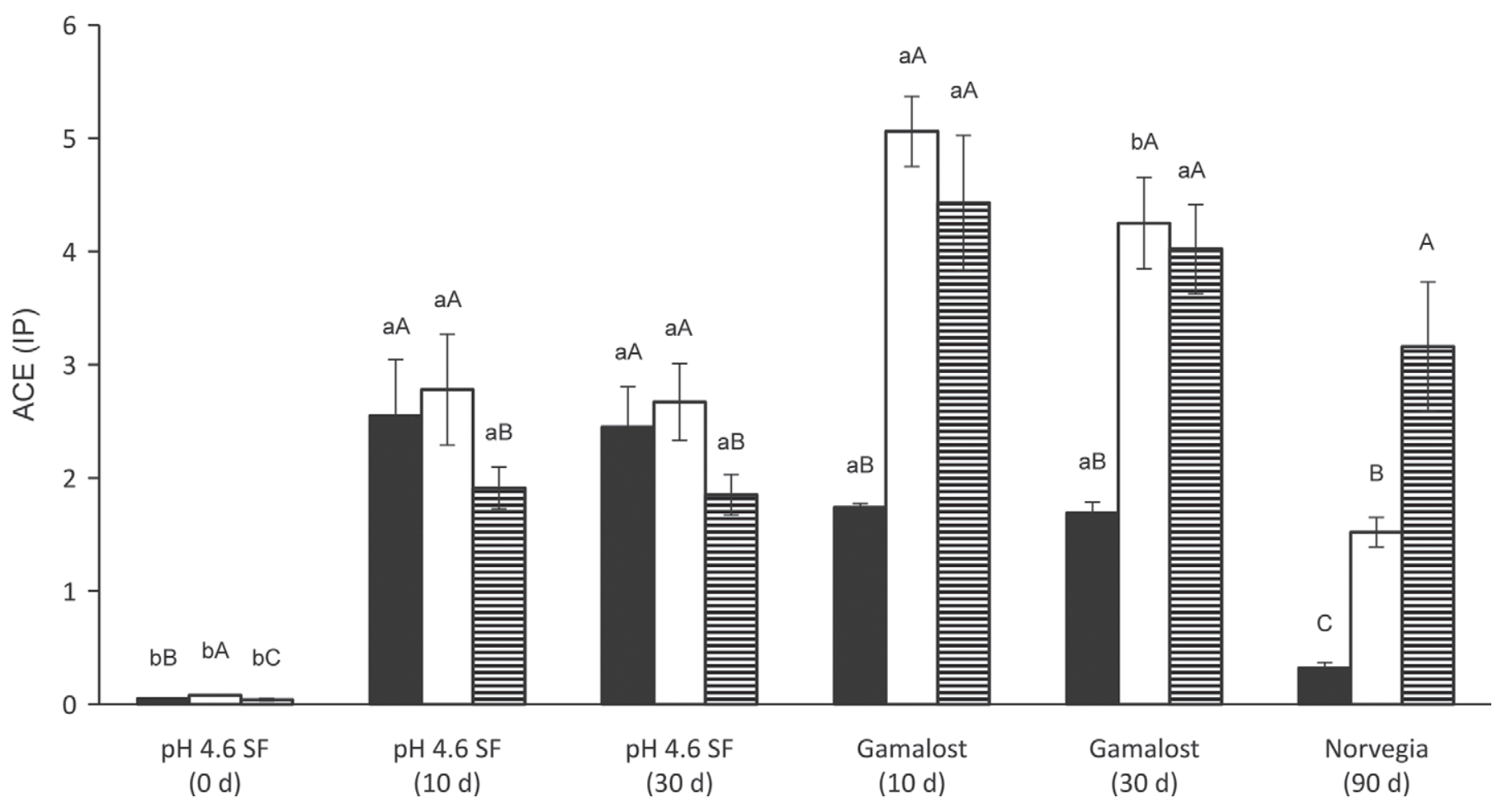

Figure 3. Angiotensin I-converting enzyme (ACE)-inhibitory potential (IP; per unit of cheese weight, expressed as milligrams of captopril equivalents per kilogram of cheese; mean $\pm \mathrm{SD}$ ) of Gamalost cheese (10 and $30 \mathrm{~d})$, its $\mathrm{pH}$ 4.6-soluble fraction (SF; 0-30 d), and Norvegia cheese before (undigested; black bars) and after gastrointestinal digestion by human gastric juice (HGJ; white bars) and human duodenal juice (HDJ; line pattern bars). Different lowercase letters (a and b) over the bars (except for Norvegia) represent significant differences $(P<0.05)$ between the ages of cheeses at the same digestion step, whereas different uppercase letters $(\mathrm{A}-\mathrm{C})$ show significant differences $(P<0.05)$ during digestion of the same sample at the same ripening stage.

bility of para- $\kappa-\mathrm{CN}$ (residues 1-105) toward hydrolysis by HGJ and HDJ. Gamalost is an acid-coagulated cheese, and the glycomacropeptide (GMP) is retained on the $\kappa-\mathrm{CN}$. However, the peptides $\kappa-\mathrm{CN}$ (149-169) and $\kappa-\mathrm{CN}$ (155-169) derived from the hydrophilic GMP were found in the undigested cheese in the $\mathrm{pH}$ 4.6 SF from the unripened Gamalost (d 0) and further degradation occurred during digestion. These peptides were not found after $30 \mathrm{~d}$ of ripening, which indicated that the GMP was completely degraded. The presence of 2 peptides, derived from $\beta-\mathrm{LG}$, following duodenal digestion revealed the presence of some whey proteins in Gamalost, which is reasonable, as the cheese was cooked in whey during manufacturing and denatured whey proteins were, therefore, retained in the cheese matrix.

Chymotrypsin, trypsin, and pepsin have specific amino acid targets during hydrolysis of proteins. It has been shown in many studies that trypsin attacks on the carboxyl side of positively charged amino acids such as Arg and Lys of the peptide sequences, as well as cleaving before Pro (Neurath, 1957; Custódio et al., 2005; Rodriguez et al., 2008). It has also been reported that chymotrypsin has a broader specificity spectrum than trypsin and, therefore, attacks on the carboxyl side of nonpolar, hydrophobic amino acids or aromatic amino acids (Tyr, Phe, and Trp; Neurath, 1957). Pepsin has been shown to hydrolyze the amino side of the Leu residues and, similar to chymotrypsin, it also attacks on the carboxyl side of the aromatic amino acids (Neurath, 1957; Auffret and Ryle, 1979). Schmelzer et al. (2007) concluded, from an in vitro peptic digestion of $\beta-\mathrm{CN}$, that pepsin cleaves the $\mathrm{C}$-terminal region that is rich in hydrophobic residues. Our findings are mostly consistent with the aforementioned reports regarding cleavage site specificities due to the activity of enzymes present in HGJ and HDJ. During HGJ digestion of 10- or 30-d-ripened Gamalost, some peptides such as $\beta-\mathrm{CN}$ (59-93), $\beta$-CN (126-140), $\beta$-CN (129-141), $\beta$-CN (193-209), and $\beta-C N$ (193-209) were generated, which have also been detected in the peptic digests of $\beta-\mathrm{CN}$ during in vitro digestion by pepsin (Schmelzer et al., $2007)$. Some of the peptides [ $\beta-\mathrm{CN}(125-140), \beta-\mathrm{CN}$ $(126-141), \beta-\mathrm{CN}(126-142), \beta-\mathrm{CN}(129-140), \beta-\mathrm{CN}$ (143-163), $\beta-\mathrm{CN}(190-209), \beta-\mathrm{CN}(191-209)$, and $\beta-\mathrm{CN}$ (192-209)] present in undigested Gamalost in the present study were also detected by Schmelzer et al. (2007) in pepsin-digested $\beta$-CN. Mucor mucedo might have a 
Table 2. Number of identified peptides in Gamalost cheese (ripened for 10 and $30 \mathrm{~d}$ ), its pH 4.6-soluble fraction (SF), and Norvegia cheese (90 d) present before (undigested samples, U) and after gastrointestinal digestion by human gastric juice (HGJ) and human duodenal juice (HDJ) ${ }^{1}$

$0 \mathrm{~d}^{2}$

\begin{tabular}{l} 
Protein type \\
\hline Gamalost cheese \\
$\beta-\mathrm{CN}$ \\
$\alpha_{\mathrm{s} 1^{-}} \mathrm{CN}$ \\
$\alpha_{\mathrm{s} 2} \mathrm{CN}$ \\
$\kappa-\mathrm{CN}$ \\
$\beta-\mathrm{LG}$ \\
Total \\
Norvegia \\
$\beta-\mathrm{CN}$ \\
$\alpha_{\mathrm{s} 1^{-}} \mathrm{CN}$ \\
$\alpha_{\mathrm{s} 2}-\mathrm{CN}$ \\
$\kappa-\mathrm{CN}$ \\
$\beta-\mathrm{LG}$ \\
Total \\
$\mathrm{pH} 4.6 \mathrm{SF}$ of Gamalost \\
$\beta-\mathrm{CN}$ \\
$\alpha_{\mathrm{s} 1}-\mathrm{CN}$ \\
$\alpha_{\mathrm{s} 2}-\mathrm{CN}$ \\
$\kappa-\mathrm{CN}$ \\
Total
\end{tabular}
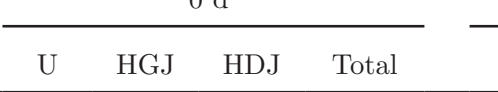

$10 \mathrm{~d}$

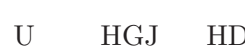

$30 \mathrm{~d}$

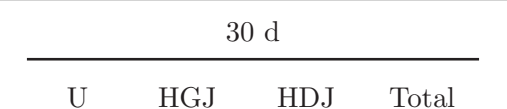
$90 \mathrm{~d}^{2}$

\begin{tabular}{llll}
\multicolumn{4}{c}{$90 \mathrm{~d}^{2}$} \\
\hline $\mathrm{U}$ & HGJ & HDJ & Total
\end{tabular}

$\begin{array}{rrrrrrrr}32 & 47 & 30 & 72 & 38 & 33 & 19 & 68 \\ 12 & 7 & 4 & 20 & 6 & 7 & 5 & 14 \\ 1 & 3 & 3 & 5 & 5 & 5 & 1 & 7 \\ 0 & 0 & 0 & 0 & 0 & 2 & 0 & 2 \\ 0 & 0 & 0 & 0 & 0 & 0 & 2 & 2 \\ 45 & 57 & 37 & 97 & 51 & 47 & 27 & 93\end{array}$

${ }^{1}$ Totals in each column correspond to the sum of the peptides derived from the different caseins in the sample. Totals in each row represent the number of different peptides (common peptides are counted only once) present before (U) and after gastrointestinal digestion by HGJ and HDJ in Gamalost, its pH 4.6 SF, and Norvegia.

${ }^{2}$ Samples were not prepared from 0-d Gamalost cheese and pH 4.6 SF from Norvegia. 


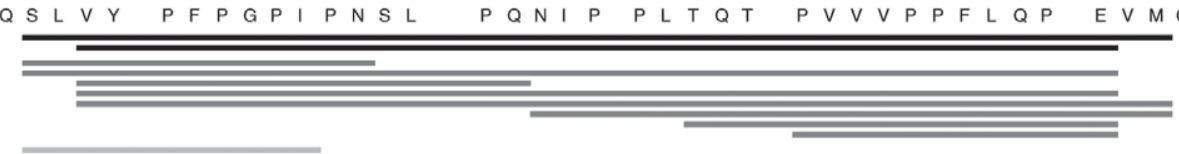
101 A MAPKHKEMP FPKYPVEPFT ESQSLTLTDV ENLHLPLPLL QSWMH QPHQP LPPTVMFPPQ SVLSLS QSKV 170

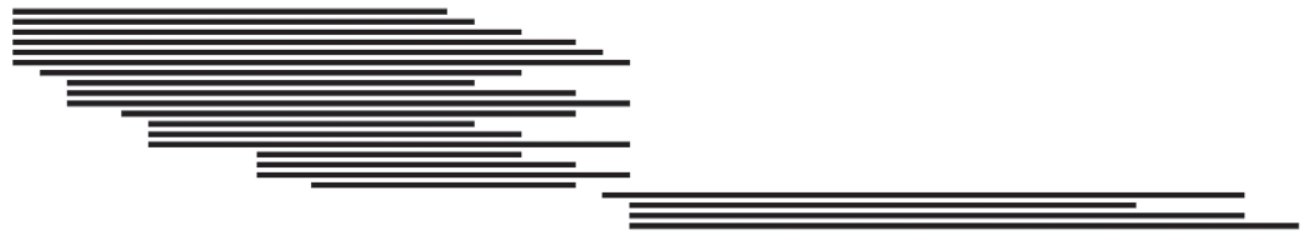

HGJ

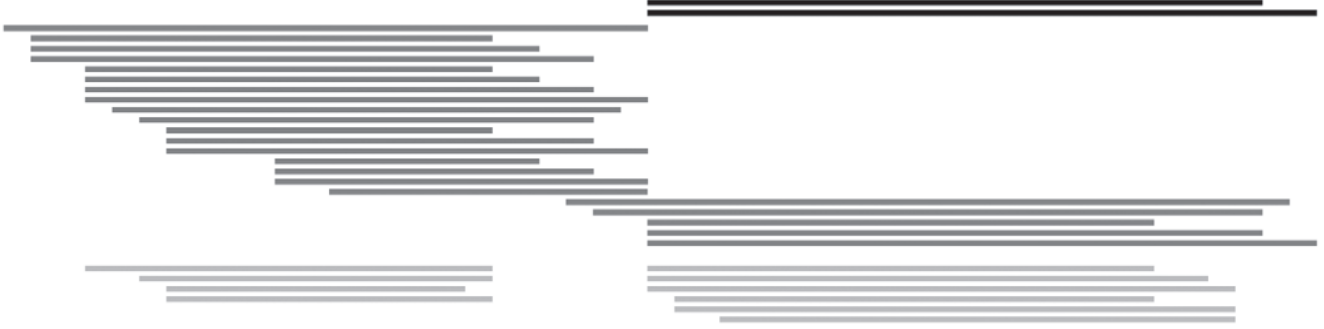

HDJ

$171 L P V P Q K A V P Y \quad P Q R D M P$ I Q A F L L Y Q P P L GP VRGPFPI I V 209

$$
\text { u }
$$

HGJ

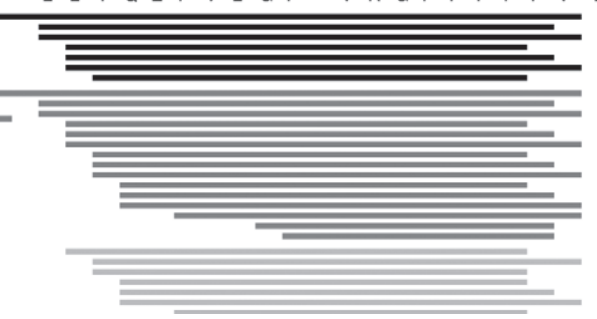

HDJ

Figure 4. The peptides derived from $\beta$-CN before (undigested; indicated by U and black lines) and after in vitro gastrointestinal digestion by human gastric juice (HGJ; dark gray lines) and human duodenal juice (HDJ; light gray lines) in the $<10-\mathrm{kDa}$ permeate of 10-d ripened Gamalost cheese. 


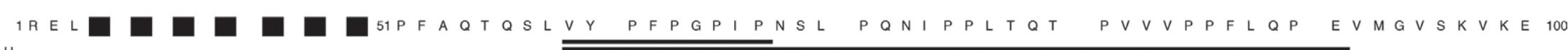

HGJ

HDJ

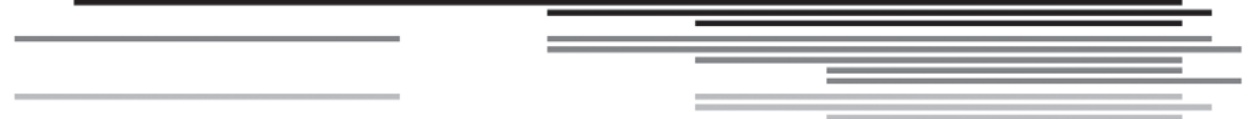

101 A M A PKHKEMP FPKYPVEPFT ESQSLTLTDV ENLHLPLPLL QSWMHQPHQP LPPTVMFPPQ SVLSL 165

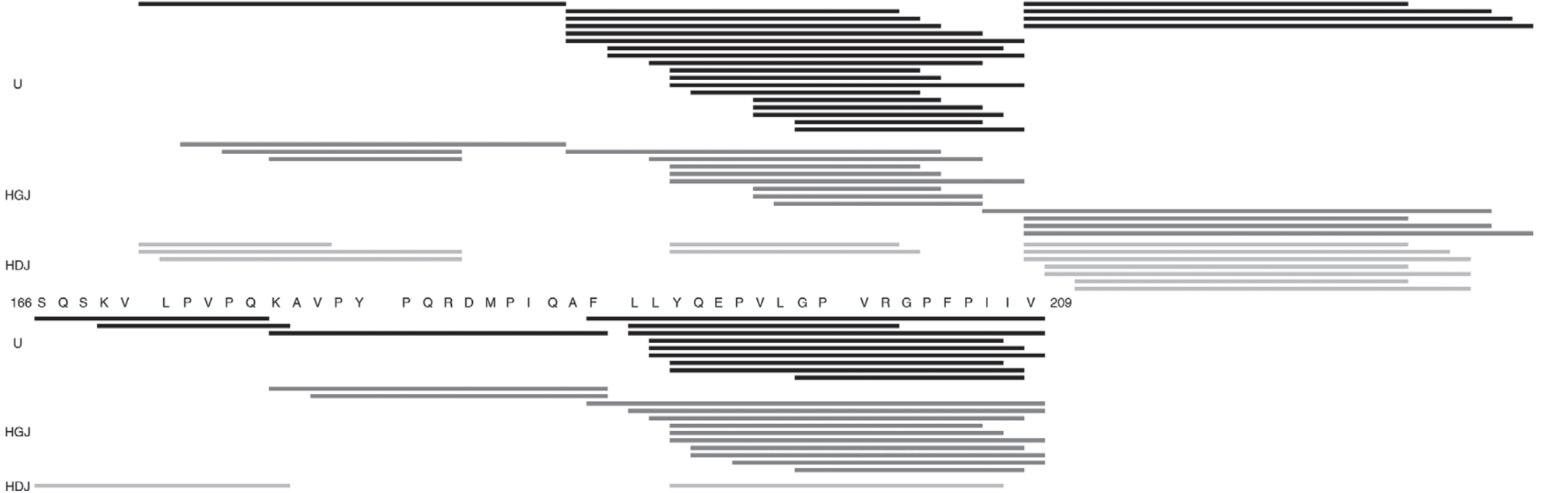

HDJ

Figure 5. The peptides derived from $\beta$-CN before (undigested; indicated by U and black lines) and after in vitro gastrointestinal digestion by human gastric juice (HGJ; dark gray lines) and human duodenal juice (HDJ; light gray lines) of the <10-kDa permeate of 30-d ripened Gamalost cheese. 


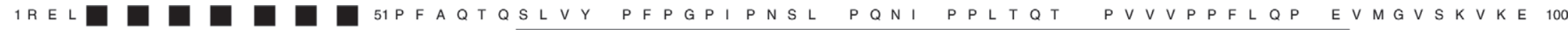

HDJ

101 A M A P K H K E M P F P K Y P V E P F T

tG.J

166 S S K V L $\overline{P V P Q K A V P Y \quad P Q R D M P I Q A F}$

u

tG.

HDJ
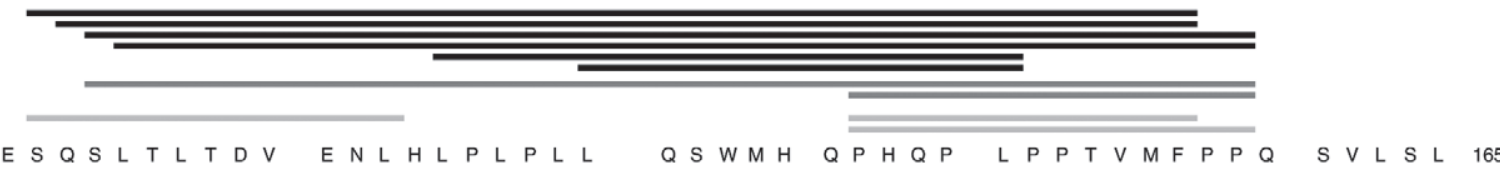

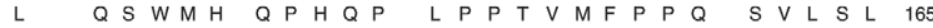

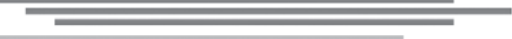

$\overline{r Q E P V L G P T R G P}$

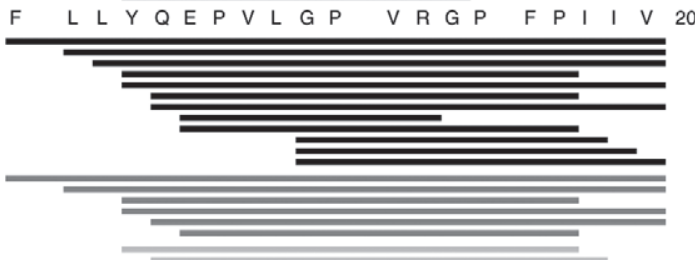

Figure 6. The peptides derived from $\beta$-CN before (undigested; indicated by U and black lines) and after in vitro gastrointestinal digestion by human gastric juice (HGJ; dar gray lines) and human duodenal juice (HDJ; light gray lines) of the $<10-\mathrm{kDa}$ permeate of Norvegia cheese.

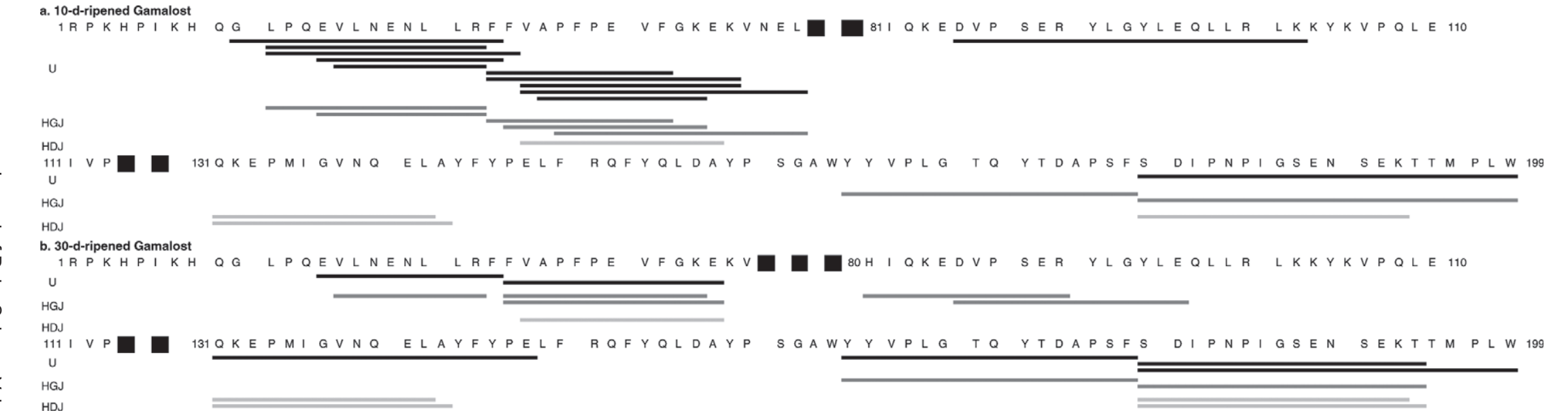

Figure 7. The peptides derived from $\alpha_{\mathrm{s} 1}$ CN before (undigested; indicated by U and black lines) and after in vitro gastrointestinal digestion by human gastric juice (HGJ; dark gray lines) and human duodenal juice (HDJ; light gray lines) of the <10-kDa permeate of Gamalost cheese. (a) 10-d-ripened Gamalost; (b) 30-d-ripened Gamalost. 


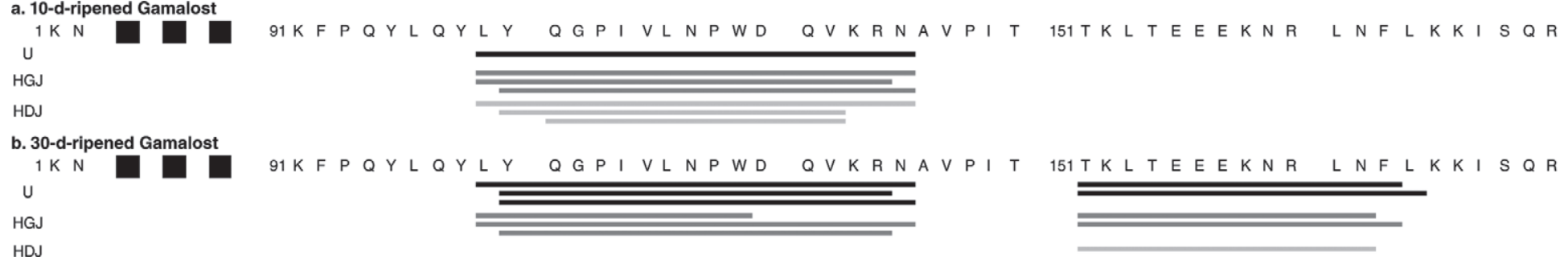

Figure 8. The peptides derived from $\alpha_{\mathrm{s} 2}$ CN before (undigested; indicated by U and black lines) and after in vitro gastrointestinal digestion by human gastric juice (HGJ; dark gray lines) and human duodenal juice (HDJ; light gray lines) of the $<10$-kDa permeate of Gamalost cheese and its pH 4.6-soluble fraction (SF). (a) 10-d-ripened Gamalost; (b) 30-d-ripened Gamalost.

Table 3. Identified peptides, with molecular mass $\left(\mathrm{M}_{\mathrm{r}}\right.$, in Da), derived from $\mathrm{\kappa}$-CN in Gamalost cheese (30 d), its $\mathrm{pH} 4.6$-soluble fraction ( $\mathrm{SF}$; 0 d), and Norvegia cheese (90 d) before (undigested samples, U) and after human gastric juice (HGJ) and human duodenal juice (HDJ) digestion

\begin{tabular}{|c|c|c|c|c|c|c|c|c|c|c|c|}
\hline \multirow[b]{3}{*}{$\mathrm{M}_{\mathrm{r}}$} & \multirow[b]{3}{*}{ Fragment } & \multirow[b]{3}{*}{ Amino acid sequence $^{1}$} & \multicolumn{3}{|c|}{$\mathrm{pH} 4.6 \mathrm{SF}$} & \multicolumn{3}{|c|}{ Gamalost } & \multicolumn{3}{|c|}{ Norvegia } \\
\hline & & & \multicolumn{3}{|c|}{$0 \mathrm{~d}$} & \multicolumn{3}{|c|}{$30 \mathrm{~d}$} & \multicolumn{3}{|c|}{$90 \mathrm{~d}$} \\
\hline & & & $\mathrm{U}$ & HGJ & HDJ & $\mathrm{U}$ & HGJ & HDJ & $\mathrm{U}$ & HGJ & HDJ \\
\hline 1584.83 & $18-30$ & F.FSDKIAKYIPIQY.V & & & & & + & & & + & \\
\hline 1796.98 & $18-32$ & F.FSDKIAKYIPIQYVL.S & & & & & & & & + & \\
\hline 1181.61 & $56-65$ & F.LPYPYYAKPA.A & & & & & + & & & & \\
\hline 2861.53 & $51-75$ & L.INNQFLPYPYYAKPAAVRSPAQILQ.W & & & & & & & & + & \\
\hline 1536.73 & $67-79$ & A.VRSPAQILQWQVL.S & & & & & & & + & & \\
\hline 1197.51 & $96-105$ & M.ARHPHPHLSF.M & & & & & & & & + & \\
\hline 1144.56 & 116-137 & D.KTEIPTINTIASGEPTSTPTTE.A & & + & & & & & & & \\
\hline 2196.06 & 149-169 & D.SPEVIESPPEINTVQVTSTAV & + & & & & & & & & \\
\hline 1226.59 & $151-161$ & P.EVIESPPEINT.V & & & + & & & & & & \\
\hline 1541.73 & $155-169$ & E.SPPEINTVQVTSTAV & + & + & + & & & & & & \\
\hline
\end{tabular}

${ }^{1}$ The dot (.) represents the cleavage site of the peptides. 

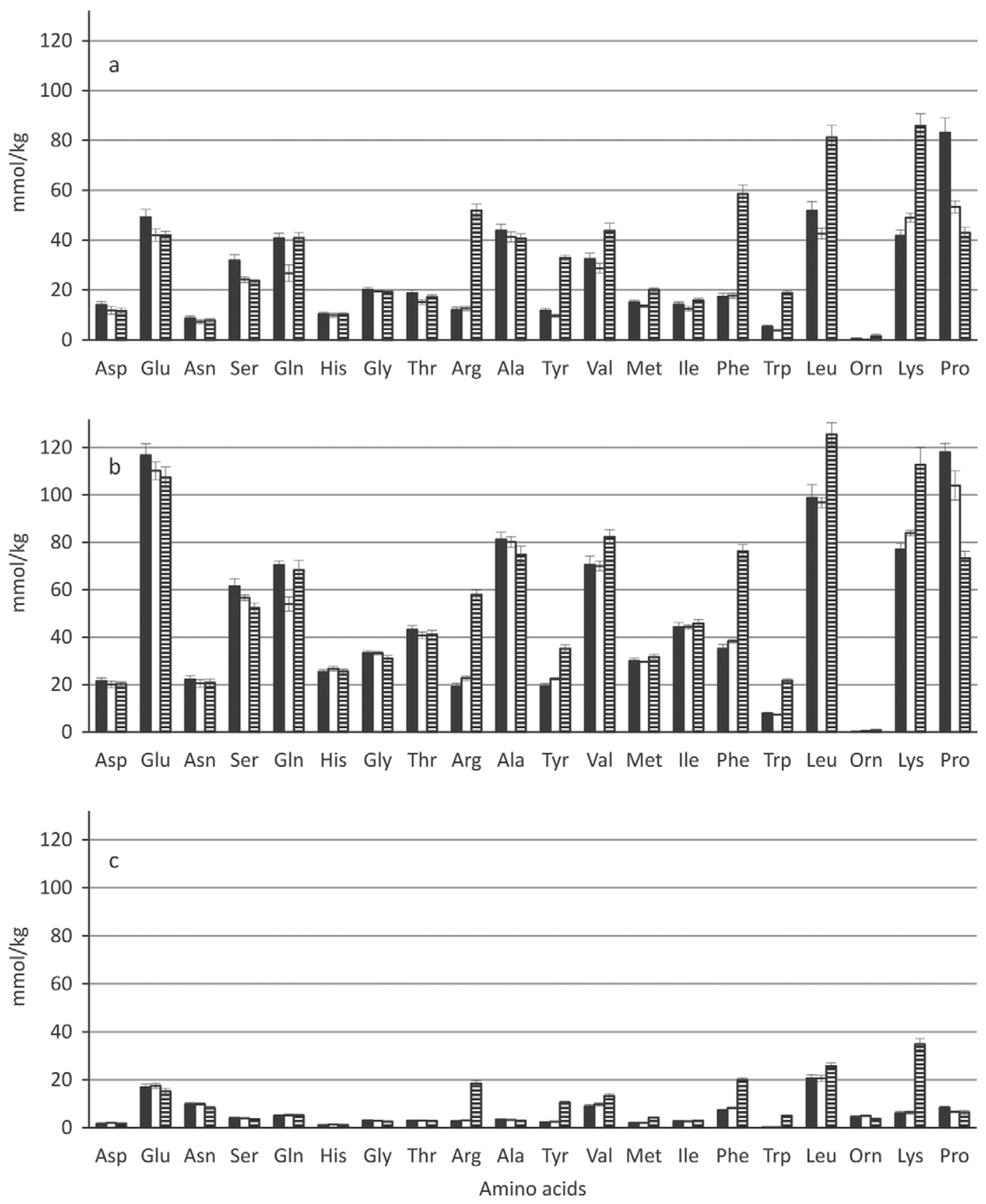

Figure 9. The concentrations ( $\mathrm{mmol} / \mathrm{kg}$ of cheese; mean $\pm \mathrm{SD}$ ) of the free amino acids (FAA) in the undigested (black bars), human gastric juice- (HGJ; white bars), and human duodenal juice- (HDJ; line pattern bars) digested Gamalost and Norvegia cheeses. (a) Gamalost ripened for 10 d; (b) Gamalost ripened for 30 d; (c) Norvegia ripened for $90 \mathrm{~d}$.

broader spectrum of cleavage specificities than pepsin, as it was observed in undigested Gamalost cheese that hydrophobic amino acids were present at the Cterminal position of the peptides. The presence of Lys and Arg at the C-terminal end of the peptides may be attributed to the action of plasmin (Upadhyay et al., 2004). However, as minor activity of plasmin (due to denaturation) was expected in Gamalost after cooking of the cheese curd in whey for 1 to $2 \mathrm{~h}$ at 90 to $95^{\circ} \mathrm{C}$, the presence of Lys and Arg at the C-terminal position of some of the peptides of Gamalost most probably were due to the activity of $M$. mucedo.

The appearance of some common peptides either after gastric digestion or duodenal digestion among $\mathrm{pH} 4.6$ $\mathrm{SF}$ of Gamalost of different ripening times $(0-30)$, as well as between 10- and 30-d-old Gamalost, might also 
indicate the common cleavage sites of peptides cleaved by HGJ and HDJ. Most reports on identification of peptides after in vitro digestion of cheese have used commercial enzymes of nonhuman origin (Abubakar et al., 1998; Gómez Ruiz et al., 2004; del Mar Contreras et al., 2009). When comparing peptides released by commercial enzymes with peptides generated with human enzymes, very few peptides matched previously reported ACE-inhibitory peptides (Schmelzer et al., 2007). Pepsin plays an important role in the primary partial digestion of protein (10 to $15 \%$ ), resulting in the production of long peptides, whereas secondary degradation of peptides was done by trypsin and chymotrypsin, resulting in oligopeptides (Goodman, 2010). More peptides were formed during gastric digestion compared with duodenal digestion, which is manifested from the number of peptides shown in Table 2.

In the present study, some peptides were not degraded and remained stable after GI digestion. If the peptides reach the cardiovascular system in an active form, they may exert a physiological (i.e., antihypertensive) effect (Segura-Campos et al., 2011). Therefore, presumable absorption of active peptides from cheese through the intestinal tract might result in a mild lowering of blood pressure. To affirm the results of our in vitro study and to clarify the bioavailability of the peptides, an epidemiological study on the effect of consumption of Gamalost on blood pressure is in progress.

\section{CONCLUSIONS}

Digestion of Gamalost with human GI enzymes increased ACE inhibition. Due to the presence of a larger amount of protein as well as a larger number of peptides (derived from $\beta-, \alpha_{\mathrm{s}^{-}}, \alpha_{\mathrm{s} 2^{-}}$, and $\kappa-\mathrm{CN}$ and $\beta-\mathrm{LG}$ ), Gamalost showed lower $\mathrm{IC}_{50}$ than Norvegia cheese even though Norvegia showed an enormous decrease in the $\mathrm{IC}_{50}$ value during gastric and duodenal digestion. Thus, both Gamalost and Norvegia might contribute to a lowering of mild hypertension, as some of the peptides remained intact during digestion and may be absorbed through the intestine.

\section{ACKNOWLEDGMENTS}

Author T. M. Qureshi is funded by the Higher Education Commission of Pakistan (Islamabad, Pakistan). The experimental work was funded by a grant from the Norwegian Research Council (Oslo, Norway), the Norwegian Foundation for Research Levy on Agricultural Products (Oslo, Norway), the Norwegian Agricultural Agreement Research Fund, and TINE SA (Oslo, Norway). The authors are grateful to TINE Meieriet Vik through their kind supply of Gamalost cheeses.
The authors are thankful to the technicians, especially Kari Ragnhild Olsen, at the dairy research group at the Department of Chemistry, Biotechnology and Food Sciences (Norwegian University of Life Sciences, Ås, Norway) for their assistance and guidance in the laboratory. The authors are obliged to Østfold Hospital Trust (Moss, Norway) for extracting the gastric and duodenal juices from volunteers. Irene Comi (Department of Chemistry, Biotechnology and Food Sciences, Norwegian University of Life Sciences, Ås, Norway) is greatly thanked for testing the activity of collected juice and also for her guidance in implementing the digestion assay. Toril Anne Grønset from the Troms $\varnothing$ University Proteomics Platform (TUPP), Department of Medical Biology, Faculty of Health Sciences, University of Troms $\varnothing$ (Troms $\varnothing$, Norway), is also thanked for running of peptide sequences.

\section{REFERENCES}

Abubakar, A., T. Saito, H. Kitazawa, Y. Kawai, and T. Itoh. 1998. Structural analysis of new antihypertensive peptides derived from cheese whey protein by proteinase $K$ digestion. J. Dairy Sci. 81:3131-3138.

Adt, I., C. Dupas, R. Boutrou, N. Oulahal, C. Noel, D. Mollé, T. Jouvet, and P. Degraeve. 2011. Identification of caseinophosphopeptides generated through in vitro gastro-intestinal digestion of Beaufort cheese. Int. Dairy J. 21:129-134.

Almaas, H., A.-L. Cases, T. G. Devold, H. Holm, T. Langsrud, L. Aabakken, T. Aadnoey, and G. E. Vegarud. 2006a. In vitro digestion of bovine and caprine milk by human gastric and duodenal enzymes. Int. Dairy J. 16:961-968.

Almaas, H., H. Holm, T. Langsrud, R. Flengsrud, and G. E. Vegarud. 2006b. In vitro studies of the digestion of caprine whey proteins by human gastric and duodenal juice and the effects on selected microorganisms. Br. J. Nutr. 96:562-569.

Auffret, C. A., and A. P. Ryle. 1979. The catalytic activity of pig pepsin C towards small synthetic substrates. Biochem. J. 179:239246.

Bütikofer, U., and Y. Ardö. 1999. Quantitative determination of free amino acids in cheese. Bull. Int. Dairy Fed. 337:24-32.

Campbell, I. 2012. The mouth, stomach and intestines. Anaesth. Intensive Care Med. 13:56-58.

Chabance, B., P. Marteau, J. C. Rambaud, D. Migliore-Samour, M. Boynard, P. Perrotin, R. Guillet, P. Jollès, and A. M. Fiat. 1998. Casein peptide release and passage to the blood in humans during digestion of milk or yogurt. Biochimie 80:155-165.

Clare, D. A., and H. E. Swaisgood. 2000. Invited review: Bioactive milk peptides: A prospectus. J. Dairy Sci. 83:1187-1195.

Custódio, M. F., A. J. Goulart, D. P. Marques, R. C. Giordano, R. L. C. Giordano, and R. Monti. 2005. Hydrolysis of cheese whey proteins with trypsin, chymotrypsin and carboxypeptidase A. Alimentos e Nutrição 16:105-109.

del Mar Contreras, M., R. Carrón, M. J. Montero, M. Ramos, and I. Recio. 2009. Novel casein-derived peptides with antihypertensive activity. Int. Dairy J. 19:566-573.

Dressman, J. B., R. R. Berardi, L. C. Dermentzoglou, T. L. Russell, S. P. Schmaltz, J. L. Barnett, and K. M. Jarvenpaa. 1990. Upper gastrointestinal (GI) pH in young, healthy men and women. Pharm. Res. 7:756-761.

Ekmekcioglu, C. 2002. A physiological approach for preparing and conducting intestinal bioavailability studies using experimental systems. Food Chem. 76:225-230.

Eriksen, E. K., H. Holm, E. Jensen, R. Aaboe, T. G. Devold, M. Jacobsen, and G. E. Vegarud. 2010. Different digestion of caprine 
whey proteins by human and porcine gastrointestinal enzymes. Br. J. Nutr. 104:374-381.

FitzGerald, R. J., B. A. Murray, and D. J. Walsh. 2004. Hypotensive peptides from milk protein. J. Nutr. 134:980S-988S.

Gómez Ruiz, J. Á., M. Ramos, and I. Recio. 2004. Angiotensin converting enzyme-inhibitory activity of peptides isolated from Manchego cheese. Stability under simulated gastrointestinal digestion. Int. Dairy J. 14:1075-1080.

Goodman, B. E. 2010. Insights into digestion and absorption of major nutrients in humans. Adv. Physiol. Educ. 34:44-53.

Haque, E., and R. Chand. 2008. Antihypertensive and antimicrobial bioactive peptides from milk proteins. Eur. Food Res. Technol. 227:7-15.

He, R., H. Ma, W. Zhao, W. Qu, J. Zhao, L. Luo, and W. Zhu. 2012. Modeling the QSAR of ACE-inhibitory peptides with ANN and its applied illustration. Int. J. Pept. 2012:620609.

Hernández-Ledesma, B., L. Amigo, M. Ramos, and I. Recio. 2004. Angiotensin converting enzyme inhibitory activity in commercial fermented products. Formation of peptides under simulated gastrointestinal digestion. J. Agric. Food Chem. 52:1504-1510.

Hyun, C.-K., and H.-K. Shin. 2000. Utilization of bovine blood plasma proteins for the production of angiotensin-I-converting enzyme inhibitory peptides. Process Biochem. 36:65-71.

IDF (International Dairy Federation). 1993. Milk. Determination of nitrogen content (Kjeldahl method). IDF Standard 20B. IDF, Brussels, Belgium.

IDF (International Dairy Federation). 1995. Milk and milk productsGuidance on sampling. IDF Standard 50C. IDF, Brussels, Belgium.

IDF (International Dairy Federation). 2004. Cheese and processed cheese-Determination of the total solids content (Reference method). IDF Standard 004/ISO 5534. IDF, Brussels, Belgium.

Kalantzi, L., K. Goumas, V. Kalioras, B. Abrahamsson, J. B. Dressman, and C. Reppas. 2006. Characterization of the human upper gastrointestinal contents under conditions simulating bioavailability/bioequivalence studies. Pharm. Res. 23:165-176.

Korhonen, H., and A. Pihlanto. 2006. Bioactive peptides: Production and functionality. Int. Dairy J. 16:945-960.

Krogdahl, A., and H. Holm. 1979. Inhibition of human and rat pancreatic proteinases by crude and purified soybean proteinase inhibitors. J. Nutr. 109:551-558.

Lignitto, L., V. Cavatorta, S. Balzan, G. Gabai, G. Galaverna, E. Novelli, S. Sforza, and S. Segato. 2010. Angiotensin-converting enzyme inhibitory activity of water-soluble extracts of Asiago d'allevo cheese. Int. Dairy J. 20:11-17.

López-Fandiño, R., J. Otte, and J. van Camp. 2006. Physiological, chemical and technological aspects of milk-protein-derived peptides with antihypertensive and ACE-inhibitory activity. Int. Dairy J. 16:1277-1293.

McCloy, R. F., G. R. Greenberg, and J. H. Baron. 1984. Duodenal pH in health and duodenal ulcer disease: Effect of a meal, Coca-Cola, smoking and cimetidine. Gut 25:386-392.

Meisel, H. 1998. Overview on milk protein-derived peptides. Int. Dairy J. 8:363-373.

Moreno, F. J. 2007. Gastrointestinal digestion of food allergens: Effect on their allergenicity. Biomed. Pharmacother. 61:50-60.

Mullally, M. M., H. Meisel, and R. J. FitzGerald. 1997. AngiotensinI-converting enzyme inhibitory activities of gastric and pancreatic proteinase digests of whey proteins. Int. Dairy J. 7:299-303.
Neurath, H. 1957. Some considerations of the multiple specificity of proteolytic enzymes. Ann. N. Y. Acad. Sci. 68:11-24.

Ohsawa, K., H. Satsu, K. Ohki, M. Enjoh, T. Takano, and M. Shimizu. 2008. Producibility and digestibility of antihypertensive $\beta$-casein tripeptides, Val-Pro-Pro and Ile-Pro-Pro, in the gastrointestinal tract: Analyses using an in vitro model of mammalian gastrointestinal digestion. J. Agric. Food Chem. 56:854-858.

Parrot, S., P. Degraeve, C. Curia, and A. Martial-Gros. 2003. In vitro study on digestion of peptides in Emmental cheese: Analytical evaluation and influence on angiotensin I converting enzyme inhibitory peptides. Nahrung 47:87-94.

Pripp, A. H., R. Sørensen, L. Stepaniak, and T. Sørhaug. 2006. Relationship between proteolysis and angiotensin-I-converting enzyme inhibition in different cheeses. Lebensm. Wiss. Technol. 39:677683.

Qureshi, T. M., G. E. Vegarud, R. K. Abrahamsen, and S. Skeie. 2012. Characterization of the Norwegian autochthonous cheese Gamalost and its angiotensin I-converting enzyme (ACE) inhibitory activity during ripening. Dairy Sci. Technol. 92:613-625. http://dx.doi.org/10.1007/s13594-012-0078-1.

Rodriguez, J., N. Gupta, R. D. Smith, and P. A. Pevzner. 2008. Does trypsin cut before proline? J. Proteome Res. 7:300-305.

Russell, T. L., R. R. Berardi, J. L. Barnett, L. C. Dermentzoglou, K. M. Jarvenpaa, S. P. Schmaltz, and J. B. Dressman. 1993. Upper gastrointestinal $\mathrm{pH}$ in seventy-nine healthy, elderly, North American men and women. Pharm. Res. 10:187-196.

Sánchez-Chiang, L., E. Cisternas, and O. Ponce. 1987. Partial purification of pepsins from adult and juvenile salmon fish Oncorhynchus keta. Effect of $\mathrm{NaCl}$ on proteolytic activities. Comp. Biochem. Physiol. B 87:793-797.

Schmelzer, C. E. H., R. Schöps, L. Reynell, R. Ulbrich-Hofmann, R. H. H. Neubert, and K. Raith. 2007. Peptic digestion of $\beta$-casein. Time course and fate of possible bioactive peptides. J. Chromatogr. A 1166:108-115.

Segura-Campos, M., L. Chel-Guerrero, D. Betancur-Ancona, and V. M. Hernandez-Escalante. 2011. Bioavailability of bioactive peptides. Food Rev. Int. 27:213-226.

Sieber, R., U. Bütikofer, C. Egger, R. Portmann, B. Walther, and D. Wechsler. 2010. ACE-inhibitory activity and ACE-inhibiting peptides in different cheese varieties. Dairy Sci. Technol. 90:47-73.

Silva, S. V., and F. X. Malcata. 2005. Caseins as source of bioactive peptides. Int. Dairy J. 15:1-15.

Ulleberg, E. K., I. Comi, H. Holm, E. B. Herud, M. Jacobsen, and G. E. Vegarud. 2011. Human gastrointestinal juices intended for use in in vitro digestion models. Food Digestion 2:52-61.

Upadhyay, V. K., P. L. H. McSweeney, A. A. A. Magboul, and P. F. Fox. 2004. Proteolysis in cheese during ripening. Page 394 in Cheese: Chemistry, Physics and Microbiology. 3rd ed. Vol. 3. P. F. Fox, P. L. H. McSweeney, T. M. Cogan, and T. P. Guinee, ed. Elsevier Academic Press, London, UK.

Vermeirssen, V., J. Van Camp, K. Decroos, L. Van Wijmelbeke, and W. Verstraete. 2003. The impact of fermentation and in vitro digestion on the formation of angiotensin-I-converting enzyme inhibitory activity from pea and whey protein. J. Dairy Sci. 86:429438. 